\title{
A Review of Local Government Institutions (LGIs) in Bangladesh
}

\author{
Jannatul Ferdous ${ }^{1}$, Saudia Hossain ${ }^{2}$ \\ 1 Department of Public Administration, Comilla University, Cumilla, Bangladesh. \\ ${ }^{2}$ Department of Public Administration, Comilla University, Cumilla, Bangladesh.
}

ABSTRACT - In Bangladesh, several renowned organizations are abundantly spoken roughly from which local government (LG) is one of them. Local Government Institutions (LGIs) take vigorous legal as well as the valid basis. This has a great legacy of inheritances for forming and developing LGIs, however the definite nature and performances in this form of organizations to increase people's involvement and increase democratic practice which is seen very limited - because of too much central involvement, and misapplication and influence by domineering governments to preserve their supremacy. The present study gives a reflective look at the development and working on local governance in decentralized form in Bangladesh, focusing on the key trends, features, and challenges. The study mainly rests on the analysis of secondary elements. LGI is still not strong and as well as not properly structured nor have enough capability consistent with the Constitutional provision but contain characteristics of deconcentration more than the pure practice of decentralization. The study is secondary literature based in nature. The findings of the present study recommend that, regardless of having the Constitutional acknowledgment of the formation of an independent and a solid local government organization, the political governance of Bangladesh has introduced diverse transformations to get variations in the organization of the LGIs in the forename of decentralization. Yet, the key aims after the most of the restructurings have been to support their political ground in the certain region. Consequently, these organizations could not be well-known as a heart of progress where societies would have the authority to observe and govern their areas.
ARTICLE HISTORY

Received: 21-04-2020

Accepted: $14-07-2020$

\section{KEYWORDS}

LGIs; decentralization; governance; politics; bureaucracy; Bangladesh

\section{INTRODUCTION}

During the eve of the twenty-first-century Local government Institutions (LGIs) faces numerous challenges in the field of service delivery, funding and investment, social assets likewise the prospects and possibilities which related with citizen's commitment and answerability and several recognized actions. In the meantime, it has been projected that the upcoming eras will observe of the necessity for improving the capability of local government which would claim for vigorous commitment and inhabitants' title role in the area of Local Government to confirm sustainable economic growth and a high value of life. In the manner of the establishing a self-governing method and governance, Bangladesh like other developing countries has acknowledged the necessity and significance of the role of LGIs (Aminuzzaman, n. d.). Through the increasing demand for good governance, it seems that proper configurations, strategies, and laws of reorganizations for forming democracy and good governance at the local level are started from time to time as essential. The present local government structure of Bangladesh has instigated from the British colonial and Pakistan period. Nevertheless, the constitution of Bangladesh has acknowledged local government institutions as a vital portion of total governance. Later, after the independence, local government organizations have reformed occasionally with diverse political rulers. Modifications or alterations have not continued for a long enough period to become rooted and be combined with an operational organization of service delivery (Nasrin, 2013). Specified those backgrounds, in this paper, we take a revising expression into the growth and operative role of decentralized local governance in Bangladesh with a view to eliciting the main trends and challenges. The key focus of the paper is to provide a comprehensive insight the regarding the diversity of challenges at the local governance challenges regarding decentralization practices in Bangladesh. The study reveals a profound insight on the challenging aspects.

\section{CONCEPTUAL CLARIFICATIONS AND LITERATURE REVIEW}

\section{Local Government (LG)}

The term Local Government can be used as that type of government who govern at the lower level or else the government who regulate in the local area (Sharmin \& Rahman, 2012). Duane Lockard explains local government as a local association authorized to select and oversees the partial series of public programs inside a comparatively minor area, 
which is a sub-sector of a local or state government. At the pyramid or hierarchy of government organizations, Local government belongs to at the last level, through the state government are at the highest where the midway governments (like states, constituencies, provinces) holding the mid-stage. Usually, local government has a common authority and is not restricted to the performance of single definite role or facility (Siddiqui, 2014).

\section{Decentralization}

Many scholars of public administration prescribed Decentralization by several means like transmission of power from an upper level of government to a lower, allocation of judgment building, settlement of power with accountability, permitting utmost figure of activities to be occupied wherever maximum of the individuals lives, elimination of roles from the focal point to the boundary, a method of actions relating broader involvement of people in the entire series of decision-making start from strategy design to application (Rondinelli \& Nellis, 1986). Basically, the concept Decentralization is much more connected to the allocation of power and authority to the local stages of government.

\section{Forms of Decentralization}

Cheema \& Rondinelli (1981) mentioned four main forms of decentralization: namely deconcentration, delegation, devolution, and deregulation which is thus given:

\section{a) Deconcentration}

To reorganize the administrative duties inside the institutions of central government with the help of sub-national and local level the term deconcentration came to the forth. Subsequently, it is viewed by means of 'shifting of workload' form head office to arena staff without shifting absolute decision. The local administration or else field division acts as a central government mediator at local, district, and sub-district level appreciates and exercises a place of giving power through this procedure. Generally, it indicates the handover of fewer important authorities to the local arms of the central government by administrative means instead of by a lawful agreement (Conyers, 1987).

\section{b) Delegation}

Delegation contains a transmission of authority, even though final control rests over the central authority. For instance, various developing countries apply this habit in the formation of boards, authorities, companies or any other distinct organizations for implementing definite purposes such as water supply, power generation and distribution, agricultural growth, rural advancement, and road-transport. Consequently, simple example reflects the decentralization in the form of delegation like allocation of power to semi-autonomous organizations separate the regular official arrangement (Ahmed, 2012).

\section{c) Devolution}

Devolution directs toward the transmission of control to locally instituted political figures. It seems to be statutory/lawful implications. Under the essence of devolution, local government is basically a form of decentralization. Democratic decentralization is another recognized term of revolutionary decentralization. Devolution is entitled political decentralization when it is mentioned as the provincial legislature (Wahhab, 2002). Rondinelli and Cheema (1933) explained the method of devolution by recognizing five major features. Firstly, authorities are moving toward selfgoverning local entities which administrated self-sufficiently without the direct regulator of the central. Secondly, legitimate authorities are assumed to the local governments to implement power above a predictable geographical region. Thirdly, the local entities have commercial prestige and supremacy to protect assets to implement their tasks. Fourthly, devolution denotes the necessity to improve local governments and associations. Lastly, it is a practice of shared, jointly valuable and corresponding interactions between central level and local level governments.

\section{d) Deregulation/ Privatization}

Transference of some formation and administrative tasks or of the public purposes of the government to nongovernment organizations such as voluntary, humanitarian, private societies signifies the last arrangement of decentralization. The procedure differs according to circumstances. In some circumstances, it includes a procedure of "debureacratization" in others a procedure of "self-management" workout and even in added as a procedure of "privatization". Patterns of such non-government organizations having this kind of transmitting duties are farmers cooperative, mutual aid societies, credit associations, specialized society, non-government organizations (NGOs) included in rustic or urban improvement, trade unions and business firms (Murshed et al, 1996).

\section{Existing LG and Decentralized Local Government Practices in Bangladesh}

In Bangladesh, the form of the local government scheme is concise in Figure 1. The local government institutions are planned with three comprehensive 'streams': Rural, Urban, and local government for distinct zones (Chittagong Hill Tracts). The typical rural local government structure contains three purposeful tiers: Zila (District), Upazila (sub-district) and Union. 
Figure 1: Tributaries and Classifications of LGIs in Bangladesh

\begin{tabular}{|c|c|c|c|}
\hline $\begin{array}{l}\text { Traditional } \\
\text { Rural- } \\
\text { Urban Divide }\end{array}$ & Territorial LGIs & Special Purpose LGIs & $\begin{array}{l}\text { General } \\
\text { LGIs }\end{array}$ \\
\hline $\begin{array}{l}\text { Rural } \\
\text { - } \quad \text { Zila Parishad } \\
\text { (61) } \\
\text { - Upazila Parishad } \\
\text { (490) } \\
\text { - Union Parishad } \\
\quad(4537) \\
\text { Urban } \\
\text { - City Corporation } \\
\text { - } \quad \text { Pourashava }\end{array}$ & $\begin{array}{ll}\text { 1. Zila Parishad in } \\
\text { plain (61) and in } \\
3 \text { in Hill Disticts } \\
\text { 2. Upazila Parishad } \\
\text { (490) } \\
\text { 3. Union Parishad } \\
\text { (4537) }\end{array}$ & 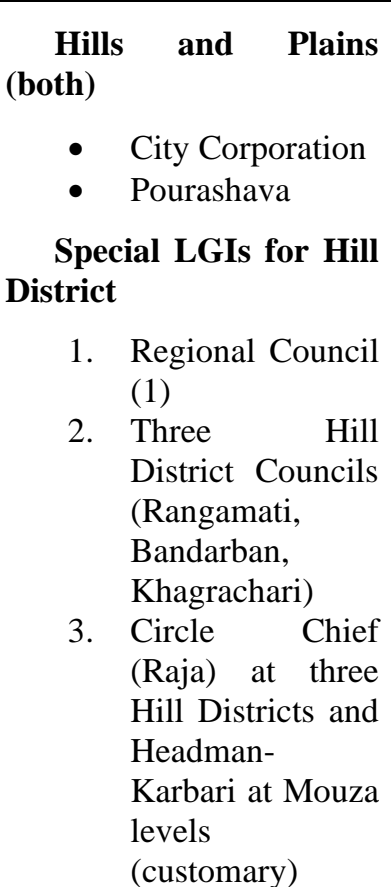 & $\begin{array}{ll}\text { 1. Zila Parishad } \\
\text { (61) in plain and } \\
3 \text { in Hill Districts } \\
\text { 2. Upazila Parishad } \\
\text { (490) } \\
\text { 3. Union Parishad } \\
\text { (4537) }\end{array}$ \\
\hline
\end{tabular}

Source: Ahmed, 2016.

Any definite acts or guidelines are not keeping an eye on the growth of local government in the Indian subcontinent. At this time, local government institutions practiced several stagy modifications in its nature which was built on the descriptive characteristics of the dominant governments. Through at the time of pre-Mughal era/ village-based local governments, for example, village council stayed in its power. Every village is capable to oversee its individual dealings. At medieval era, village administration was structured by the Village Panchayat. For accumulating revenues/ sustaining rule and command, overseeing education, irrigation, religious customs, and ethical manners of the villagers -the Panchayat was responsible for this. Later, during the Mughal period, the revenue collection scheme developed much more efficient and the local administration converted itself with more forceful in this respect. In this age, Sarkar/ Chakla, and Pargana developed as the center area of overall and revenue administration (Khan, 2011).

The colonial attentions of the British Empire's in decentralized administration matched with persons belong to the Muslims and concentrated on the revenue task of the nation to preserve the industrial revolution at home. By the Permanent Settlement Act of 1793, a faithful landowning class of Zamindars was formed, whose main work is to 'deinstitutionalized' the internal rural administrations in Bengal and delivered a dominant rule with the help of comprehensive revenue and also with political provision basis. To safeguard the colonial benefits in local regions, a sequence of supplementary organizations and regulations were presented sequentially as the Chowkidary Panchayat Act 1870, Local Self-Government Act 1885, and Bengal Village Self-Government Act 1919 (Khan, 2016).

In 1947, from the British rulers, of the Indian sub-continent acquired freedom further this India and Pakistan arose as two sovereign and self-governing nations. As we know, current Bangladesh became a portion of Pakistan. At Pakistan Period (1947-71) which was marked for reinforcing the nearly declining local government structure. One of the notable strength starts with Basic Democracies (BD) which was a four-tier scheme of local government, whose work during the early sixties- with the initial purpose of shaping the public to pay attention of the difficulties of their regions and instructing them in essence of self-depended, nonetheless formal regulator at each and every part shaped it hard for the people's legislative body to act efficiently (Murshed et al., 1996).

The configuration of the local government forms has experienced numerous variations, after the independence of Bangladesh in 1971. Instantaneously afterward of independence, the Union Panchayat was renamed from Union Council, where an administrator was employed. The Thana Council was entitled as Thana Development Committee; however, the District Council developed as the Zila Board or the District Board. In 1973, the title of Union Panchayat was returned to Union Parishad. A new momentous revolution was carried nearby through the Local Government Ordinance, 1976 (Panday, 2011). Consequently, numerous modifications had arisen in stages, the method of election, configuration, and improvement purposes, power-sharing and so on. It is worth stating that, the greatest substantial modifications on the way to decentralization were prepared by the announcement of Local Government ordinance 1982 through starting to elect Upazila scheme. Meanwhile that, LGIs has been portrayed extra duties to start enlargement programs and provide 
appropriate and actual facilities to encounter the claim of local people. In this prospect, it would be moderately related to recapping that throughout the British along with the Pakistan period LGIs were accountable merely for upholding law and order, and an increase in revenue. In the 1990s, in Bangladesh democracy was reestablished and from then forwards, the course of globalization has witnessed when the country arriving into the free market economy. Both the domestic and international sectors have been attained much more prominence in Bangladesh- by the democratic political entity. Consequently, Bangladesh arrived into the progression of good governance with the modification in the progression belief meanwhile 1990s and connection with the notion of new liberalism. So, the possibility of LGIs was once more renowned in relations of people's participation, responsibility, transparency, operational service delivery and gender equilibrium in upgrading deliberation. Thus, the significance of decentralized local government has been acknowledged by the Government of Bangladesh as an active organization to develop governance and encourage improvement. In recent times, a sum of Acts was circulated through which LGIs have been initiated as important agencies in executing lower level method of progress. The significance of participation of community people by announcing Wardshava and Ward committee meeting (meeting with community people at Ward level), sharing budget planning (e.g., open budget meeting) and so on was identified by the Local Government (Union Parishad) (Amendment) Act 2010 and Local Government (Paurashava) (Amendment) Act 2010. Instead of, systematic elections of those organizations guaranteed devolution from diverse standpoints similar to political, financial, and administrative (Barkat et al, 2015).

In spite of these advantages, Bangladesh is motionless at the crossway in guaranteeing decentralized local government. LGIs have quietly been distressed from the absence of the robust promise of the government to institutionalize the essence of decentralization.

\section{METHODOLOGICAL FOCUS}

The article is basically developed on the basis of secondary works in the particular study area. Data were generated from the secondary literature like books, journal articles, research reports and internet browsing.

\section{EXPERIMENTAL RESULTS KEY TRENDS AND CHALLENGES OF DECENTRALIZED LOCAL GOVERNANCE IN BANGLADESH}

Based on the exceeding historical analysis, a study of the most important literature, and personal understandings, this unit provokes certain characteristic trends and challenges of decentralized local governance in the Bangladesh.

\section{Conflicting Political Culture}

In numerous developing countries, the precondition for the achievement of decentralization arises between the exercising of democratic political values and political will. Nevertheless, democratic political culture has not yet been developed in Bangladesh moreover inside or amongst the political parties. Countless scholars claimed that the core reason of poor governance in Bangladesh is the political difficulties and the political structure of the nation which has rotated to the course of criminalization and commercialization of political affairs. It has been instituted that the fights between the political parties mark it difficult to encourage decentralization policy in the state. However, in 1991, the state initiated to transmit it to democracy by mass revolution among high hopes of insertion and contribution, consequent developments do not appear that democratic practices are combined, despite five general elections observed from 1991 to till (Panday \& Asaduzzaman, 2011). Political parties and their leaders' initiatives and approaches undoubtedly exhibit that they favor control of their own party at the local level instead of executing decentralization dogma. Decentralization has been a widespread word in political rhetoric and it has continued so in political assurances rather than in actuality.

\section{Bureaucratic Elitism}

Generally, bureaucracy is a dynamic portion of current states and nobody can disrespect the significance of upholding a skilled bureaucracy (Panday \& Asaduzzaman, 2011). On the other hand, an indifferent bureaucracy is continuously a warning to democratic political organizations in some developing country. Comparable with other developing countries, Bangladesh belongs to the hereditary bureaucratic elitism from the British colonial rule (Zafarullah, 2007). After independence, the dimension of the civil service takes to double up. This undoubtedly settles that the central government is actually widened in place of the local government. Bureaucratic development of the phase of decreasing local government authority recommends indirectly that bureaucratic conflict to local government modification carried on subsequently (Rahman, 2010).

\section{Inadequate Capability of Local Government Institutions}

It is clear that the technical capability of local government bodies, particularly at the Union level, is very poor. The applicable regulations and ordinances demand for an extensive sort of growing tasks and roles for those organizations; maximum local government staff consume narrower or no capability to accomplish these recommended technical starring roles. Moreover, human assets and logistics are usually at the nominal level, which transforms these organizations unproductive, particularly to play a projected role of a society to motivate as 'change agent' (Khan, 2016). 


\section{Insufficient Resource Organization}

Traditionally, for upholding simple day-to-day doings local government organizations, even have depended on central funds. Such kind of central subsidy usually derives in the method of 'block grants' and formerly projected assistances. Those funds continue as a key possibility for central influence and interference. Struggles in the direction of local resource utilization have been inadequate with tiny achievement. The causes comprise the unwillingness on the share of local government, political front-runners impose taxation trials for the fright of dropping reputation in the middle of voters, few technical capability etc.

\section{Insufficient Financial Resources}

The LG bodies in Bangladesh suffer from some short of financial funds and capital which is universally observed. Through adapting those issues into attention, the LG principles specify the LG forms with the authority to utilize capital from local assets through charging taxes, 'hat-bazaar' lease, etc. While the UP engenders capitals from diverse bases, it does not collect its overall portion. By the Annual Development Program (ADP) every UP collects donations from the national government, which was an extra part of concern in that case. On the other hand, it is firmly stated in the rules that the LG entities must practice this block assistance in certain areas which was agreed by the central government. This kind, of course, hinders the development procedure of the LG for the reason that it is not capable to combine the instant locality's wants into the policies, nevertheless the LG desires to work on the plans delivered by the Government (Panday, 2011). These sorts of dominance have taken the LG rely on the central government, which is conflicting to the actual ideologies of the decentralized local government forms.

\section{Lack of Constancy}

Since the Bangladesh era, with diverse political rules, local government organizations have reformed occasionally. For numerous political approach modifications or restructuring have not continued for extensive enough periods. A common scenario is always seen that one political regime does not like and carry on previous government's doing. Because of the absence of constancy of organization and purposes, the local government institutions continued, fewer active roles and ineffective in executing allocated activities. By the alteration of government, variations in stages of local forms have made misunderstanding in the thoughts of people, which constructing it hard for local figures worried to perform any act title role for the lack of constancy (Hasan, 2007).

\section{Lack of Trained Personnel}

Lack of proper competence structuring the use of empowerment is zero. So as to reinforce the LG figures, the organized capability in relations of both social proficiency and logistics needs to be supported. Sufficient knowledge and understanding of the functioning measures and purposes of those forms do not have most of the chairman as well as members of the LG entities. Furthermore, they have the absence of suitable understanding which is essential to the transaction with the complex directions of budgeting, planning, and handling assets. Besides, the elected officers and paid staff of the LG entities are not assumed sufficient training to mark them skilled of bearing a notable workload (Panday, 2011).

\section{Domination of Local Elite}

At the local level, one of the main barriers for upholding good governance and institutionalization of democracy contains the supremacy and authority of the local elite. It may be assumed that such influence would mark ways for them to generate an auspicious situation for retrieving in the local government and take part in the local level decision-making procedure and as a result, it creates a connection with center control (Nasrin, 2013).

\section{Least Amount of Popular Participation}

By such (above-mentioned) drifts as bureaucratization of the local government organizational tackle, withdrawal of locality precise political space, and influenced election schemes, the amount, and unit of community participation in local government decisions and movements have been borderline - to say the least. The assignation of local groups in local government actions has usually been in such practices as salaried-labor efforts in numerous infrastructural schemes, and receivers or 'target beneficiaries' of several community safety nets and development systems (Khan, 2016).

\section{CONCLUSION AND WAY FORWARD}

To set the entire situation on a single canvas: the local government policy method is obscure and categorized by inherent action by lawmakers and political-leaders. The strategic places of the main people in politics, administration and civil society are somewhat out of sight. The political elite have time and again shown a double ordinary approach with rhetoric and indecision. Insufficient public place and support linkages cannot continuously agree the champions like local government organization leaders and civil society campaigners to show their level (Rahman, 2013). There is enough scope to do studies on the loopholes of the present study and on the findings of the study. The study provides an arena of future research on the basis of the key challenges of the decentralized local government scheme in Bangladesh. Based on the secondary findings of the study, researchers can do an empirical study of the prevailing issues. Some probably recommended hints on upgrading this system- comprising those are:

- Proper usage and enlargement of the probable of the current styles in better fiscal allocation at the local level, 
- Accomplishing the policy restructuring procedure,

- On the portion of the ruling government, an actual amount of open political promise is preserved,

- A robust political vision is desired to create the local government forms more influential by decentralizing control of the center,

- Better application of the local political space by local campaigners,

- Shape the capability structuring programs for the elected local government representatives so that they can formulate themselves to competently release their duties,

- A distinct and independent local government commission would be recognized to supervise all the matters connecting to the local government facts.

\section{REFERENCES}

Ahmed, T. (2016). Bangladesh: Reform Agenda for Local Governance. Dhaka: Prothoma Prokashan.

Ahmed, T. (2012). Decentralization and the Local State. Dhaka: Agamee Prakashani.

Aminuzzaman, S. (n. d.). Political Economy of Local Governance: A Study of the Grassroots level Local Government in Bangladesh. Retrieved from: http://paperroom.ipsa.org/papers/paper_30718.pdf

Barkat, A., Khan, S. H., Majumder, S., Badiuzzaman, M., Sabina, N., Ahamed, K. \& Abdullah, M. (2015). Local Governance and Decentralization in Bangladesh: Politics and Economics. Dhaka: Pathak Shamabesh.

Conyers, D. (1987). Decentralisation: A Theoretical Framework- A Lecture Note in the Centre for Development Studies (February), University College of Swansea, Swansea (unpublished).

Hasan, S. (2007). Women in Bangladesh Local Government, Dhaka. A H Development Publishing House.

Khan, M. M. (2011). Local Government in Bangladesh: Some Contemporary Issues and Practices. Dhaka: A H Development Publishing House.

Khan, N. A. (2016). Challenges and Trends in Decentralised Local Governance in Bangladesh. ISAS Working Papers, No. 222. Institute of South Asian Studies, National University of Singapore.

Murshed, S. M., Quddus, M. A., Rahman, S. A., Ahmed, A., Chowdhury, M. A. \& Rahman, M. (1996). Decentralization of Administration in Bangladesh with Cases of Two Upazilas and Some Perspective Issues. Comilla: BARD.

Nasrin, F. (2013). Reforms in Local Government: Experiences from Bangladesh. Journal of Asia Pacific Studies, 3(1), pp. 37-56.

Panday, P. K. \& Asaduzzaman, M. (2011). "Politics, Problems and Trends of Decentralized Local Governance in Bangladesh" in: I., Jamil, S. M., Aminuzzaman, S. Askvik, \& S. T. M. Haque, eds. Understanding Governance \& Public Policy in Bangladesh. Dhaka: MPPG Program, North South University, pp.153-174.

Panday, P. K. (2011). Local Government System in Bangladesh: How Far is it Decentralised? Journal of Local SelfGovernment, 9(3), pp. 205-230.

Rondinelle D. A. \& Nellis, J.P. (1986).Assessing Decentralization on Policies in Developing Countries: The Case for Cautions Optimism. Development Policy Review, 4, Sage Publication, London.

Rondinelli, D. (1981). Government Decentralization in Comparative Perspective: Theory and Practice in Developing Countries. International Review of Administrative Sciences, 47(2), pp. 133-145.

Rahman, M. H. (2013). Local Government Reforms in Bangladesh: Hazy Policy Landscape. In: Vartola, J., Lumijarvi, I. \& Asaduzzaman, M. (eds.) Towards Good Governance in South-Asia. Dhaka: Osder Publications.

Rahman, M. H. (2010). Local Government Reforms in Bangladesh: Hazy Policy Landscape. In: Vartola, J., Lumijarvi, I. \& Asaduzzaman, M. (eds.) Towards Good Governance in South-Asia (pp. 245-260). University of Tempere Press.

Rondinelli, D. A. \& Cheema, G. A. (1983). Implementing Decentralization Policies: An Introduction. In G. S. Cheema \& D. A. Rondinelli (eds.). Decentralization and Development: Policy Implementation in Developing Countries. Beverly Hills, Calif: Sage.

Sharmin, Z., Haque, M. A., \& Islam, F. (2012). Problems of Strengthening Local Government in Bangladesh: Towards a Comprehensive Solution. SUST Studies, 15(1), pp.76-84.

Siddiqui, K. (2014). Local Government in Bangladesh: Revised Third Edition. Dhaka: The University Press Limited.

Wahhab, M. A. (2002). Decentralization in Bangladesh: Theory and Practice. Dhaka: Osder Publications.

Zafarullah, H. (2007). Bureaucratic Elitism in Bangladesh: The Predominance of Generalist Administrators. Asian Journal of Political Science, 15 (2), pp. 161-173. 


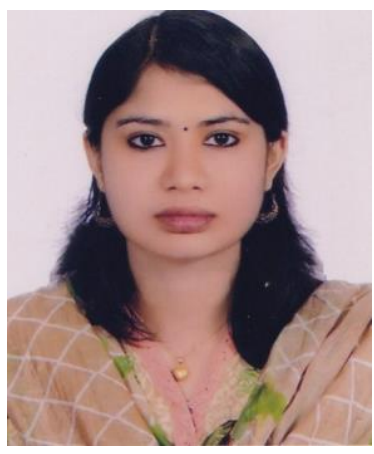

Jannatul Ferdous is serving as an Assistant Professor, Department of Public Administration,Comilla University, Bangladesh. She received the B. S. S. (Hons) degree and M. S. S. degree in Public Administration from University of Dhaka, Dhaka, Bangladesh in 2008 and 2009 respectively. She completed her M. Phil in Public Administration, University of Dhaka. At present, she is doing PhD. at Department of Development Studies, University of Dhaka. She is a contributor of a number of research articles in various reputed national and international journals and five books. Currently, she is serving as a Chair of the technical committee of 'Combating Gender Based Violence' project of UN Women. Her current interest of research includes governance, e-governance, trust, civil service system, gender, public policy, climate change, gender and development.

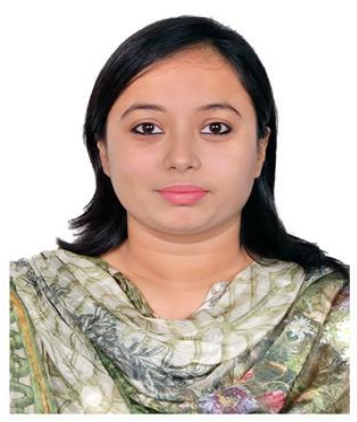

Saudia Hossain accomplished her M. S. S. and B. S. S. degree in Public Administration from Comilla University, Comilla, Bangladesh in 2011 and 2012 respectively. She acted as a former intern of mPower Social Enterprise Ltd. as a resarch and data anaysts on the subjectmatternof e-primary education. She devoted herself on numerous resarch work from where one article published on international journal. In the future, she hopes to continue her resarch work on the field of local government, issues on climate change, decentralization of government work etc. 